\title{
Who gets irritable bowel syndrome and does seeing a gastroenterologist affect its course?
}

\author{
Charles N Bernstein MD FRCPC
}

\begin{abstract}
CN Bernstein. Who gets irritable bowel syndrome and does seeing a gastroenterologist affect its course? Can J Gastroenterol 2001;15(Suppl B):5B-7B. A review of studies involving patients with irritable bowel syndrome is presented. This review looks at the impact of gastroenterology consultation on health care utilization patterns and the well-being of the patient when followed up over a two-year period. A structured gastroenterological consultation between the physician and patient may decrease the number of office visits for gastrointestinal-related problems.
\end{abstract}

Key Words: Irritable bowel syndrome

\section{Syndrome du côlon irritable : qui en est} atteint et le fait de consulter un gastro-entérologue en modifie-t-il le cours?

RÉSUMÉ : Le présent article fait un survol des études sur les patients atteints du syndrome du côlon irritable. On y traite de l'incidence des consultations en gastro-entérologie sur l'utilisation des services de santé ainsi que sur le bien-être des patients suivis sur une période de deux ans. Une consultation structurée entre le gastro-entérologue et le patient peut réduire le nombre de visites en cabinet pour des troubles digestifs liés au syndrome.
A lterations in bowel habit, abdominal pain, abdominal distention or any combination of these symptoms are among the most common reasons for patients to consult with their physicians. When these symptoms conform to the Manning criteria or the Rome criteria, a diagnosis of irritable bowel syndrome (IBS) is made. If patients do not have sufficient Manning or Rome criteria, then they may be labelled as having IBS-type symptoms.

\section{HOW COMMON IS THIS PROBLEM?}

Prevalence rates of IBS over the past two decades have ranged from $9 \%$ to $23 \%$, depending on the nature of the study performed (Table 1). For instance, in populationbased surveys, rates have been $9 \%$ (United States house- holder's survey [1]) and 13\% (Australia [2]). Rates have been as high as $23 \%$ in family practice settings in the United Kingdom (3). The study of prevalence rates through a doctor's office includes a selection bias of subjects who present to the doctor and may bias the data toward higher rates. Nearly $50 \%$ of the population may have IBS-type symptoms but not meet the Manning or Rome criteria for IBS (Table 1).

\section{WHAT MAKES A SUBJECT WITH IBS OR IBS-TYPE COMPLAINTS SEEK MEDICAL ATTENTION?}

Two distinct studies suggested that being a woman increased the likelihood of seeking medical attention by $20 \%$ to $30 \%$ (Table 2) $(4,5)$. One study was from general practice in the

\footnotetext{
University of Manitoba, Inflammatory Bowel Disease Clinical and Research Centre, Winnipeg, Manitoba

Correspondence: Dr CN Bernstein, 804F-715 McDermot Avenue, John Buhler Research Centre, Winnipeg, Manitoba R3E 3P4. Telephone 204-787-1434, fax 204-789-3897, e-mail cbernstein@cc.umanitoba.ca
} 


\section{TABLE 1}

Prevalence of irritable bowel syndrome (IBS)

\begin{tabular}{|c|c|c|c|c|c|}
\hline $\begin{array}{l}\text { Author } \\
\text { (reference) }\end{array}$ & Location & $\mathbf{n}$ & $\begin{array}{c}\text { IBS } \\
\text { prevalence } \\
(\%)\end{array}$ & $\begin{array}{l}\text { Other } \\
\text { IBS-type } \\
\text { (\%) }\end{array}$ & Comments \\
\hline $\begin{array}{l}\text { Harvey et al } \\
\text { (10) }\end{array}$ & UK & 1925 & 23 & 10 & Gl clinic \\
\hline $\begin{array}{l}\text { Jones and } \\
\text { Lydeard (5 }\end{array}$ & 5) UK & 1620 & 22 & 25 & GP practices \\
\hline $\begin{array}{l}\text { Heaton et al } \\
\text { (3) }\end{array}$ & UK & 1896 & 9 & 38 & GP practices \\
\hline $\begin{array}{l}\text { Drossman } \\
\text { et al (1) }\end{array}$ & US & 5430 & 9 & 44 & Householder \\
\hline $\begin{array}{l}\text { Talley et al } \\
\text { (6) }\end{array}$ & $\begin{array}{c}\text { Olmsted, } \\
\text { MN }\end{array}$ & 835 & 17 & 46 & Population-based \\
\hline $\begin{array}{c}\text { Talley et al } \\
\text { (11) }\end{array}$ & Olmsted & 919 & 14 & NS & $\begin{array}{c}\text { 30-49 years } \\
\text { Population-based }\end{array}$ \\
\hline $\begin{array}{l}\text { Talley et al } \\
\text { (7) }\end{array}$ & Olmsted & 3022 & 18 & NS & Population-based \\
\hline $\begin{array}{l}\text { Talley et al } \\
\text { (2) }\end{array}$ & Australia & 730 & 13 & NS & Population-based \\
\hline
\end{tabular}

Gl Gastrointestinal; GP General practitioner; MN Minnesota; NS Not significant; UK United Kingdom; US United States

United Kingdom (5) and one study was a United States householder survey (4). Other studies suggested that having abdominal pain (Olmsted County, Minnesota [6,7], United Kingdom [3] and Australia [2]) increased the likelihood of medical attention, and this association correlated with severity or intensity of pain (Table 2).

\section{WHAT PREDISPOSES PEOPLE TO IBS?}

There is an emerging consensus that patients with IBS may be genetically predisposed and may have suffered an important intestinal insult (ie, a past infection). There is a widely held view that these patients are more likely to have endured major psychosocial trauma, or currently are enduring major chronic life stress or may simply be more likely to have concurrent psychiatric disorders. No discreet cause of IBS has ever been discerned, and it is extremely unlikely that a single cause will ultimately account for all cases. In fact, because there are several clinical subsets of IBS (diarrhea-predominant, constipation-predominant, mixed bowel habit pattern, pain-predominant), there are likely several etiological pathways that lead to IBS. For some patients there may be a sensorineural disturbance at a peripheral (gut) or central level. For other patients there may be primary intestinal motor disturbances. For some patients no neurophysiological disturbances may be discerned. IBS is not an inflammatory disorder, but the likelihood that a prior inflammatory event occurred in some patients is plausible.

Investigators have pursued studies regarding life stress, psychiatric diagnoses and sexual abuse. There are data suggesting that IBS patients are more likely to have been sexually or physically abused at some time in their lives than patients with organic gut disorders or no disorders at all.

\section{TABLE 2}

Health care seeking in prior year and predictors

\begin{tabular}{|c|c|c|c|}
\hline \multirow{2}{*}{$\begin{array}{l}\begin{array}{l}\text { Author } \\
\text { (reference) }\end{array} \\
\text { Jones and } \\
\quad \text { Lydeard (5 }\end{array}$} & $\begin{array}{r}\text { Preva } \\
\text { Study ca }\end{array}$ & $\begin{array}{r}\text { evalence rate } \\
\text { (rate of heal } \\
\text { care seeking) }\end{array}$ & 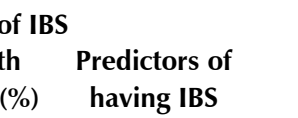 \\
\hline & UK GP practices & $22(7)$ & Being female $(\mathrm{OR}=1.2)$ \\
\hline $\begin{array}{l}\text { Heaton et al } \\
\text { (3) }\end{array}$ & UK GP practices & $9(5)$ & $\begin{array}{c}\text { Abd pain } \\
(\mathrm{OR}=12.6,6.9-23 \text { men }) \\
(\mathrm{OR}=6.0,3.8-9.5 \\
\text { women })\end{array}$ \\
\hline $\begin{array}{l}\text { Talley et al } \\
\text { (6) }\end{array}$ & $\begin{array}{c}\text { Olmsted } \\
\text { population-based }\end{array}$ & $13(9)$ & $\begin{array}{c}\text { Severe abd pain } \\
(\mathrm{OR}=3.2,2.2-4.9) \\
\text { Pain } \geq 1 / \mathrm{wk} \\
(\mathrm{OR}=3.9,2.8-5.5) \\
\text { Pain } \geq 2 \mathrm{~h} \\
(\mathrm{OR}=2.7,1.9-3.9) \\
\text { Pain interrupting daily } \\
\text { activities } \\
(\mathrm{OR}=3.7,2.5-5.4)\end{array}$ \\
\hline $\begin{array}{l}\text { Talley et al } \\
\text { (7) }\end{array}$ & $\begin{array}{c}\text { Olmsted } \\
\text { population-based }\end{array}$ & $25(8)$ & $\begin{array}{c}\text { Abd pain infrequent- } \\
\text { severe }(\mathrm{OR}=2.8-13.7) \\
\text { began }<1 \text { year prior } \\
(\mathrm{OR}=1.6,1.3-2.0) \\
\mathrm{Abnormal} \mathrm{BM} \\
(\mathrm{OR}=1.8,1.3-2.4) \\
\text { Nausea several times/wk } \\
(\mathrm{OR}=1.6,1.2-2.2) \\
\text { BMs interrupting daily } \\
\text { life }(\mathrm{OR}=1.6,1.1-2.5)\end{array}$ \\
\hline $\begin{array}{l}\text { Drossman } \\
\text { et al (4) }\end{array}$ & US householder & $45(23)$ & Being female $(\mathrm{OR}=1.3)$ \\
\hline $\begin{array}{l}\text { Talley et al } \\
\text { (2) }\end{array}$ & $\begin{array}{c}\text { Australia } \\
\text { population-based }\end{array}$ & $13(10)$ & $\begin{array}{c}\text { Pain severity } \\
(\mathrm{OR}=2.1,1.1-4.0) \\
\text { Pain duration } \\
(\mathrm{OR}=1.5,1.1-2.1)\end{array}$ \\
\hline
\end{tabular}

Abd Abdominal; BM Bowel movement; GP General practitioner; IBS Irritable bowel syndrome; OR Odds ratio; UK United Kingdom; US United States; wk Week

Because much of the sexual abuse data come from specialized centres, it is hard to know how much the data reflect the general population. For subjects who complete population surveys, it is hard to know whether patients who have been sexually abused would be more or less likely to answer those questions. Past sexual abuse is common in society and, thus, its role as a predisposing factor in IBS must be carefully weighted (Table 3 ).

One type of IBS that may be short lived is postinfectious IBS. In a study performed through travel clinics in Winnipeg in 1999 (8), it was found that the incidence of new onset IBS post-traveller's diarrhea was as low as approximately $2 \%$ in people who were completely healthy before travel. Up to $6 \%$ of people may develop new gut symptoms that, as a whole, do not qualify under Manning or Rome criteria as IBS. These numbers may seem to be small; however, they may contribute a significant burden on the population, considering the extent of travel to areas with high risks of associated traveller's diarrhea, and considering that subjects often travel recurrently, not simply once in a lifetime. 


\section{TABLE 3}

\section{Literature review of abuse and gastrointestinal illness}

Abuse history, psychiatric disturbance and medical symptoms are significantly associated

Abuse history is more commonly reported by women

Abuse history is more common in referral practice than in primary care

Patients with functional gastrointestinal disorders report abuse more frequently than patients with organic disorders

Abuse history is associated with an increased tendency to seek health care and poorer health status (psychological dysfunction, symptom reporting, more frequent surgery)

Patients' physicians are usually unaware of the history of abuse

Data from reference 5

\section{REFERENCES}

1. Drossman DA, Li Z, Andruzzi E, et al. U.S. householder survey of functional gastrointestinal disorders. Prevalence, sociodemography, and health impact. Dig Dis Sci 1993;38:1569-80.

2. Talley NJ, Boyce PM, Jones M. Predictors of health care seeking for irritable bowel syndrome: a population based syndrome. Gut 1997;41:394-8.

3. Heaton KW, O'Donnell LJ, Braddon FE, Mountford RA, Hughes AO, Cripps PJ. Symptoms of irritable bowel syndrome in a British urban community: Consulters and nonconsulters. Gastroenterology 1992;102:1962-7.

4. Drossman DA, Talley NJ, Leserman J, Olden KW, Barreiro MA. Sexual and physical abuse and gastrointestinal illness. Review and recommendations. Ann Intern Med 1995;123:782-94.

5. Jones R, Lydeard S. Irritable bowel syndrome in the general population. BMJ 1992;304:87-90.

6. Talley NJ, Zinsmeister AR, Van Dyke C, Melton LJ III. Epidemiology
It has been suggested that the depth of the physicianpatient interaction and the time that the physician spends discussing the patient's symptoms and concepts regarding IBS should enhance patient outcome. Ilnyckyj et al (9) undertook a study in Winnipeg through the offices of two academic-based and two private practice-based gastroenterologists to determine the impact of gastroenterology consultation on health care utilization patterns and the well-being of the patient when followed up over a two-year period. The authors' preliminary data reveal that, after a structured gastroenterology consultation, the number of office visits for gastrointestinal-related complaints and for psychiatric complaints significantly diminishes in the first year postconsultation, whereas all other visit types did not change. Data on well-being are forthcoming.

of colonic symptoms and the irritable bowel syndrome.

Gastroenterology 1991;101:927-34.

7. Talley NJ, Zinsmeister AR, Melton LJ III. Irritable bowel syndrome in a community: symptom subgroups, risk factors, and health care utilization. Am J Epidemiol 1995;142:76-83.

8. Ilnyckyj A, Choudri SH, Dverksen D. Association of travel related diarrhea (TD) with irritable bowel syndrome (IBS): is postinfectious IBS a true entity? Gastroenterology 1999;116:A1011.

9. Ilnyckyj A, Graff L, Blanchard JF, Yu N, Rawsthorne P, Bernstein CN. Impact of gastroenterology consultation on health care utilization in patients with IBS. Gastroenterology 2000;118:A145.

10. Harvey RF, Salih SY, Read AE. Organic and functional disorders in 2000 gastroenterology outpatients. Lancet 1983;i:632-4.

11. Talley NJ, Fett SL, Zinsmeister AR, Melton LJ III. Gastrointestinal tract symptoms and self-reported abuse: a population-based study. Gastroenterology 1994;107:1040-9. 


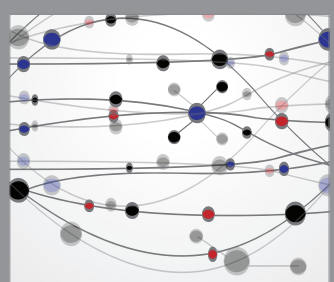

The Scientific World Journal
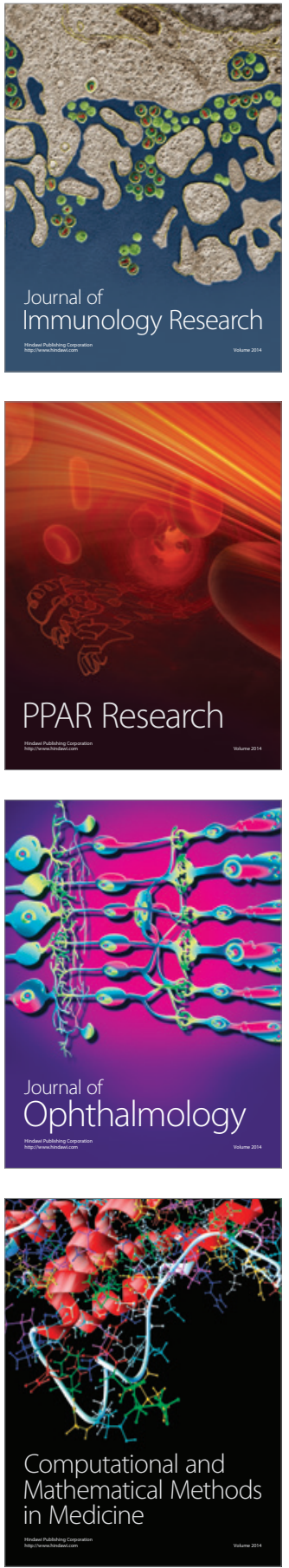

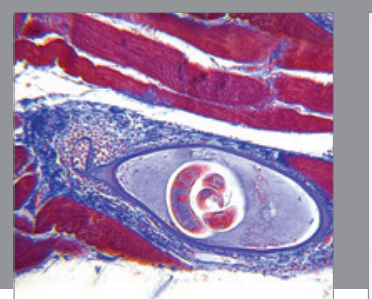

Gastroenterology Research and Practice

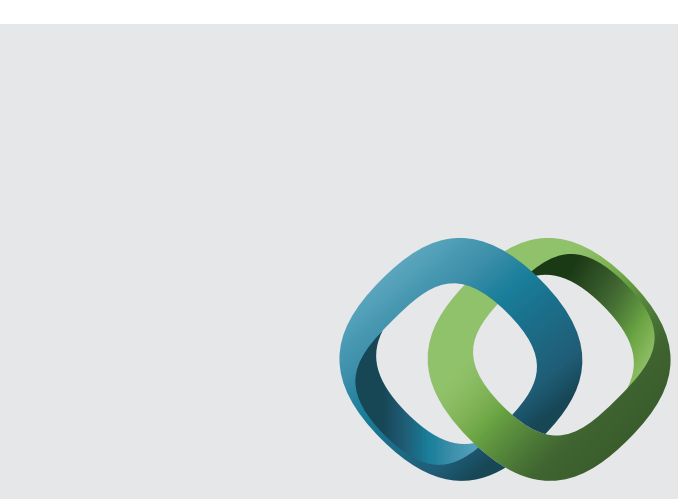

\section{Hindawi}

Submit your manuscripts at

http://www.hindawi.com
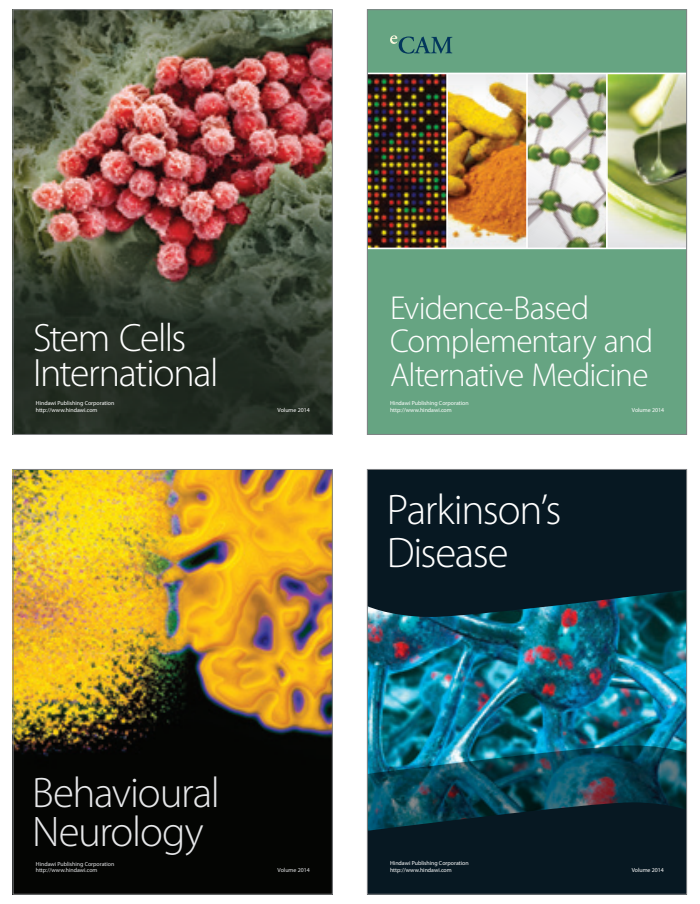
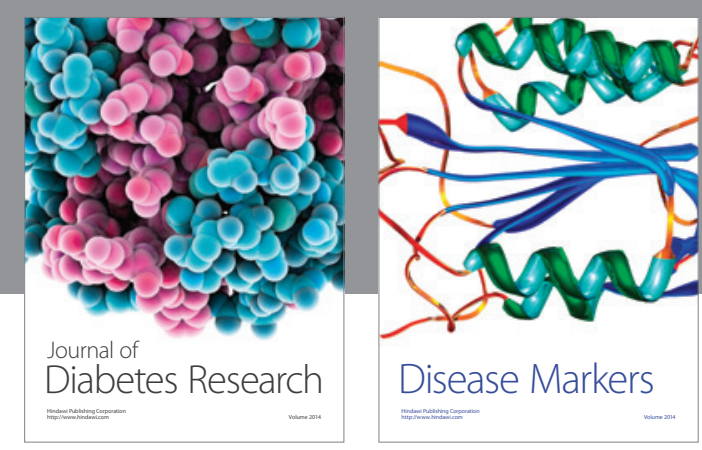

Disease Markers
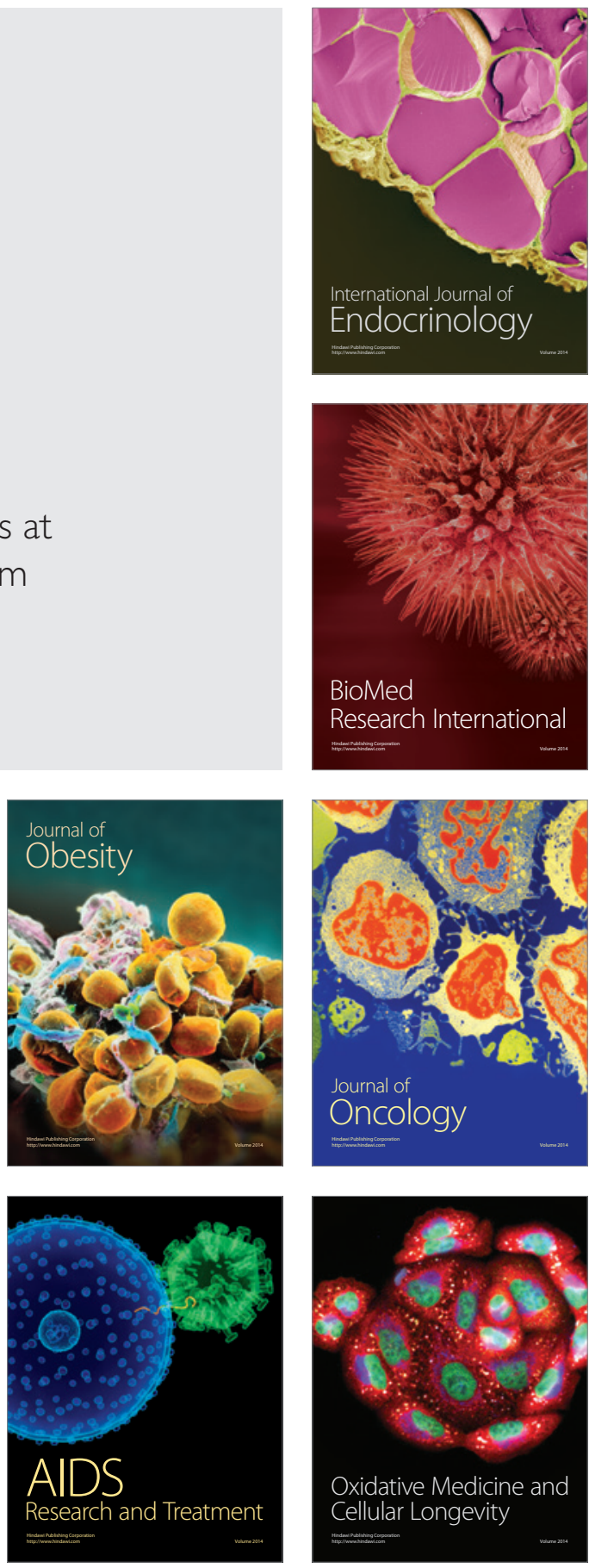